\title{
Rancang Bangun Kursi Penderita Cereblal Palsy
}

\author{
Muhammad Arsyad ${ }^{1, \mathrm{a}}$ dan A.M. Anzarih ${ }^{1, \mathrm{~b}}$ \\ ${ }^{1}$ Jurusan Teknik Mesin, Politeknik Negeri Ujung Pandang, Jalan Perintis Kemerdekaan KM.10 Makassar, 90245, Indonesia \\ a arsyadhabe@poliupg.ac.id, \\ b anzarih@ poliupg.ac.id
}

\begin{abstract}
The general goal of this research is to help provide a means to train the muscles of the sufferers Cerebral Palsy (CP). In especially, the objectives are: (1) Make a seat that has a function like easy stand, (2) Provide easy stand chair at a price affordable by people suffering from CP. Problems to be solved through applied product research activities are (1) how to make a chair that has functions such as easy stand, (2) how to provide easy chair seat with low price that can be reached by $\mathrm{CP}$ sufferer. To achieve these goals be done designing and making a chair similar to chair easy stand for people with CP. Stages of activities include designing, manufacturing components, assembling, testing and repair. Based on the test results, it is concluded that the celebral palsi chairs function well, including the components such as knee retention, peut holder, and table. The price of one CP chair is Rp 10 million.
\end{abstract}

Keywords—chair, Celebral Palsy, therapy

Abstrak- Tujuan umum yang hendak dicapai dalam kegiatan penelitian ini yaitu untuk membantu menyediakan sarana untuk melatih otot para penderita Celebral Palsi (CP). Secara khusus, tujuan yang hendak dicapai yaitu (1) Membuat kursi yang memiliki fungsi seperti easy stand, (2) Menyediakan kursi "easy stand" dengan harga yang terjangkau oleh masyarakat penderita CP. Permasalahan yang hendak diselesaikan melalui kegiatan penelitian Produk Terapan ini yaitu (1) Bagaimana membuat kursi yang memiliki fungsi seperti easy stand, (2) Bagaimana menyediakan kursi "easy stand" dengan harga murah yang dapat dijangkau oleh penderita $\mathrm{CP}$. Untuk mencapai tujuan tersebut maka dilakukan perancangan dan pembuatan kursi yang mirip dengan kursi easy stand bagi penderita CP. Tahapan-tahapan kegiatan meliputi perancangan, pembuatan komponen, perakitan, uji coba dan perbaikan. Berdasarkan hasil pengujian, disimpulkan bahwa kursi celebral palsi berfungsi dengan baik, termasuk komponen-komponennya seperti penahan lutut, penahan peut, dan meja. Harga satu buah kursi CP ialah sebesar Rp 10 juta.

Kata Kunci-kursi, celabral palsi, terapi

\section{Pendahuluan}

Cerebral palsy (CP) merupakan penyebab umum terjadinya cacat fisik pada anak. Cerebral palsy atau biasa disebut Cereblal Palsi (CP) bukanlah suatu penyakit, melainkan merupakan cedera neurologis non progresif yang merupakan gangguan kontrol otot dan koordinasi yang disebabkan oleh cedera otak sebelum atau selama kelahiran atau pada anak usia dini. Penyandang cacat dapat di klasifikasikan sebagai berikut, penyandang cacat fisik, cacat mental, dan cacat ganda. CP merupakan salah satu bentuk brain injury, yaitu kondisi yang mempengaruhi pengendalian sistem motorik sebagai akibat terganggunya suatu jaringan dalam otak. Akibat adanya disfungsi otak, maka penyandang CP mempunyai kelainan pada fungsi gerak dan koordinasi, psikologis, dan kognitif yang mempengaruhi proses belajar mengajar. Selain mengalami kesulitan belajar dan perkembangan fungsi kognitifnya, penderita CP seringkali mengalami kesulitan dalam komunikasi, persepsi, maupun kontrol gerakan. Gangguan fungsi kognitif yang terjadi mulai dari yang ringan sampai yang berat. $\mathrm{CP}$ dapat memiliki dampak yang luar biasa pada kapasitas anak untuk melakukan kegiatan sehari-hari seperti kemampuan untuk berjalan atau berpakaian. Anak yang menerita $\mathrm{CP}$ menampakkan gejala kesulitan dalam hal motorik halus (menulis atau menggunakan gunting), masalah keseimbangan, berjalan, atau mengenai gerakan involunter (tidak dapat mengontrol gerakan menulis atau selalu mengeluarkan air liur) dan jika sudah mencapai derajat berat akan mengakibatkan tidak mampu berjalan dan membutuhkan perawatan yang ekstensif dalam jangka panjang [1]. 
Gangguan gerakan pada CP sering disertai dengan gangguan sensasi, persepsi, kognisi komunikasi, perilaku, dan terkadang disertai serangan epilepsi dan masalah muskuloskeletal sekunder. CP dapat berdampak pada keadaan psikis seperti kurangnya ketenangan. Anak yang menerita $\mathrm{CP}$ tidak dapat stabil baik dalam hal fisik seperti sulit duduk tegak maupun dalam hal emosinya, sehingga menyulitkan pendidik untuk mengarahkan kepada suatu pelajaran atau latihan. Penderita $\mathrm{CP}$ dapat juga bersikap depresif, melihat sesuatu dengan putus asa atau sebaliknya agresif seperti pemarah, ketidaksabaran atau jengkel, yang akhirnya sampai kejang [2]. Jumlah penderita $\mathrm{CP}$ di dunia mencapai 17 juta jiwa lebih, dan di Indonesia menurut dr Uni Gamayani, spesialis syaraf di Departemen Neurologi Rumah Sakit Hasan Sadikin Bandung, setiap 2 dari seribu kelahiran hidup menderita $\mathrm{CP}$, dengan tingkat keparahan mulai dari yang ringan sampai yang berat. Selain bawaan lahir, CP dapat juga terjadi akibat kecelakaan, sebagaimana yang dikemukakan orang tua salah satu penderita CP pada Rumah Sakit Wahidin Sudirohusodo Makassar (RSWS), bahwa anaknya menderita CP setelah mengalami kecelakaan, dimana pada saat mengalami kecelakaan, kepala anaknya mengalami benturan. Dari uraian di atas, disimpulkan bahwa kerusakan otak pada penderita $\mathrm{CP}$ berdampak pada kelainan fisik, kelainan psikologis, kelainan mobilitas, kelainan komunikasi, kelainan mental dan intelegensi sehingga harus selalu dibantu orang lain untuk dapat melakukan kegiatan, bahkan dari hal kecil seperti duduk tegak, berjalan, makan, sampai kegiatan belajar mengajar. Salah satu metode yang digunakan untuk membantu para penderita CP yaitu melalui latihan-latihan gerakan atau terapi fisioterapi dengan menggunakan berbagai alat bantu, misalnya alat bantu jalan. Alat bantu jalan pasien merupakan alat bantu jalan yang digunakan pada penderita/pasien yang mengalami penurunan kekuatan otot dan patah tulang pada anggota gerak bawah serta gangguan keseimbangan [3]. Alat bantu jalan berupa kursi yang fungsinya untuk menyangga berat badan, kursi roda merupakan alat bantu yang digunakan oleh orang yang mengalami kesulitan berjalan menggunakan dua kaki. Alat-alat tersebut biasa dipakai oleh para fisioterapis untuk menunjang pekerjaanya sebagai seorang fisoterapis. Namun alat bantu tersebut belum cukup untuk menunjang para fisioterapis dalam merehalibilitasi pasien dikarenakan jumlah fisioterapis terbatas serta jumlah media terapi yang tidak sebanding dengan jumlah pasien yang terus meningkat.

Penderita penyakit $\mathrm{CP}$ atau kelumpuhan otak besar termasuk cacat fisik, yang mana penderita penyakit ini mengalami kekakuan otak, kelumpuhan dan gangguan fungsi saraf lainnya [2]. Survey awal di SLB "X" Bandung. Di sekolah tersebut terdapat 64 siswa yaitu 30 siswa tingkat SDLB, 20 siswa tingkat SMPLB, dan 14 siswa tingkat SMALB. Latar belakang kondisi yang berbeda pada siswasiswa tersebut beragam, diantaranya adalah keterbelakangan mental, autis, cerebral palsy, down syndrom, ADHD (Attention Deficit Hyperactive Disorders), serta tunawicara. Sebagian besar siswa tersebut (21 siswa) didiagnosa mengalami $\mathrm{CP}$, yang memiliki derajat keparahan sedang hingga berat. Penderita CP berbeda dengan penyandang tunadaksa. Individu yang mengalami tunadaksa sama sekali tidak dapat menggerakkan bagian tubuhnya yang mengalami gangguan atau kerusakan, sedangkan individu CP masih dapat menggerakkan anggota tubuhnya yang terserang meskipun gerakan terganggu karena adanya kelainan pada tonus otot [4]. Salah satu alat bantu yang digunakan oleh fisioterapis yaitu kursi yang biasa disebut easy stand (ES). Kursi tersebut dapat digerakkan secara manual dengan bantuan hidrolik atau dengan motor. Dengan bantuan hidrolik, kursi tersebut dapat membantu penderita CP untuk merubah posisi duduknya hingga berdiri tegak secara bertahap. Dr. Asmaun Najamuddin, SpKF-R, salah satu staf rehabilitasi medik di Rumah Sakit Wahidin Sudirohusodo (RSWS) Makassar menyatakan bahwa kursi ES di Indonesia Timur hanya ada 1 (satu), yaitu yang dimiliki RSWS Makassar. Untuk memperoleh alat tersebut, pihak RSWS membeli dari Amerika Serikat dengan biaya yang tidak sedikit, sekitar US $\$ 2.340$ ( $R p 31.590 .000$ dengan kurs $\mathrm{Rp} 13.500$ ). Dengan harga seperti itu, menyebabkan keluarga pasien tak mampu untuk mengadakannya. Alat yang dimiliki RSWS tersebut digerakkan secara manual dengan sistem hidrolik, pernah mengalami kerusakan yaitu adanya kebocoran pada sistem hidrolik sehingga tidak dapat digunakan dalam waktu lama. Alat tersebut berhasil diperbaiki oleh tim peneliti di Bengkel Otomotif Politeknik Negeri Ujung Pandang. Kegiatan perbaikan 
yang dilakukan yaitu penggantian oil seal yang mengalami kerusakan yang disebabkan oleh lamanya pemakaian. Berdasarkan penjelasan di atas maka permasalahan yang hendak diselesaikan yaitu: (1) Bagaimana membuat kursi yang memiliki fungsi seperti easy stand, (2) Bagaimana menyediakan kursi yang mirip "easy stand" dengan harga yang dapat dijangkau oleh masyarakat penderita CP.

\section{Metode Penelitian}

Kegiatan penelitian ini, dilaksanakan selama 8 (delapan) bulan bertempat di Bengkel Mekanik, dan Bengkel Otomotif Jurusan Teknik Mesin Politeknik Negeri Ujung Pandang. Sedangkan bahan-bahan yang digunakan akan dibeli dari toko-toko bahan bangunan yang ada di Makassar, kecuali hidroliknya dibeli di Jakarta. Bahan-bahan yang digunakan dalam penelitian ini yaitu: dongkrak hidrolik, pipa glvanis, elektroda las, mata gerinda, cat dan kelengkapannya, bahan-bahan untuk dudukan dan sandaran kursi, meja, handle dan kawat rem, roda. Sedamgkan peralatan yang digunakan dalam pembuatan kursi ES tersebut, semuanya tersedia di Politeknik Negeri Ujung Pandang seperti: mesin las, mesin gerinda, mesin bubut, mesin frais, mesin bor, dan kunci-kunci untuk perakitan.

Metode penanganan masalah dilakukan dengan cara merancang dan membuat Kursi Celebral Palsi (KCP) dengan model yang mirip dengan ES. Metode penanganan masalah tersebut dibagi menjadi tiga tahap yaitu: Tahap I merupakan tahap perancangan, Tahap II merupakan tahap pembuatan dan perakitan, dan Tahap III merupakan tahap pengujian dan perbaikan. Kegiatan awal yang dilakukan untuk merealisasikan penelitian ini yaitu melakukan perancangan terhadap alat yang akan dibuat. Perancangan yang dilakuan didasari dua hal pokok yaitu (1) siapa penggunanya, dan (2) bentuk yang mirip dengan ES. Dimensi alat tentu sangat dipengaruhi oleh siapa pengguna alat tersebut. Alat ini proyeksikan akan digunakan oleh remaja dan orang dewasa, artinya tidak diperuntukkan buat anak-anak. Kelompok remaja disini anak-anak yang berumur sekitar 17 tahun atau kelompok yang duduk di Sekolah Menengah Umum atau sederajat. Alat yang akan dibuat memiliki bentuk yang mirip dengan easy stand namun fungsinya sama dengan easy stand. Alat ini dibuat sedemikian rupa, sehingga penderita bisa memanfaatkan alat ini untuk melatih pergerakan ototnya terutama otot kaki, dari posisi duduk hingga berdiri dengan gerapan tahap demi tahap. Demikian pula sebaliknya yaitu dari keadaan berdiri hingga duduk. Alat ini juga akan dilengkapi dengan roda sehingga memungkinkan untuk dipindahkan, meskipun untuk memindahkan penderita masih membutuhkan bantuan orang lain karena rodanya belum dilengkapi dengan motor penggerak. Kegiatan berikutnya ialah Pembuatan dan perakitan komponen. Pada tahapan ini, dilakukan pembuatan komponen-komponen KCP seperti rangka, kursi, dudukan tangan, dan meja. Setelah komponen-komponen tersebut dibuat, langkah selanjutnya yaitu merakit antara komponen yang satu dengan komponen lainnya menjadi satu kesatuan menjadi KCP. Kegiatan terakhir yaitu Pengujian, perbaikan, dan pengecatan. Kegiatan selanjutanya setelah perakitan ialah pengujian KCP. Pengujian dilakukan untuk mengetahui perikatan antara komponen yang satu dengan dengan komponen lainnya, dan pengujian fungsi dari KCP tersebut. Pengujian fungsi dilakukan dengan tanpa beban, dan dengan beban. Pengujian fungsi ini dilakukan untuk gerakan naik, dan turun. Pengujian dengan beban dilakukan beberapa kali dengan beban yang berbeda-beda, yaitu antara $40 \mathrm{~kg}$ s.d $90 \mathrm{~kg}$. Apabila dalam pengujian tersebut terdapat permasalahan baik dari segi perikatan komponennya maupun dari fungsinya, maka akan dilakukan kegiatan perbaikan hingga tidak ada lagi masalah yang terjadi sehingga KCP dapat digunakan secara baik dan aman.

\section{Hasil dan Pembahasan}

Gambar 1(a) memperlihatkan KCP inventaris Rumah Sakit Wahidin Sudirohusodo, sedangkan Gambar 1 (b) merupakan KCP produk penelitian.

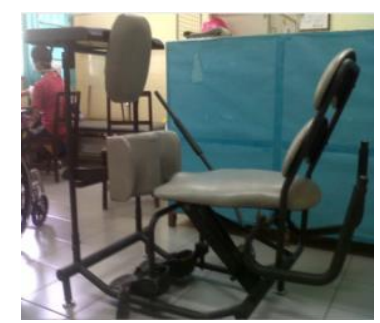

(a)

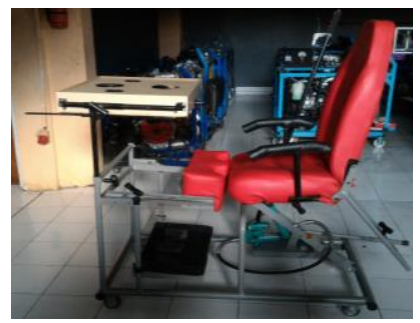

(b)
Gambar 1. Kursi Celebral Palsy 
Tabel 4.1 menunjukkan hasil pengujian yang dilakukan terhadap KCP. Pada pengujian1 (mengatur posisi meja), sampel $\mathrm{C}$ dan $\mathrm{D}$ mampu mengatur posisi meja naik-turun dan maju-mundur walau sedikit kesulitan pada saat menaikkkan meja. Sampel A, B dan E tidak mampu untuk menaikkan posisi meja, sehingga dibutuhkan orang lain untuk menaikkan posisi meja. Hal tersebut terjadi karena gesekan pada stand meja serta berat meja itu sendiri. Jadi, untuk menaikkan posisi meja tanpa bantuan orang lain diperlukan fisik yang kuat. Untuk pengujian 2 (mengatur posisi penahan lutut), sampel A, B, C, D dan E mampu mengatur posisi penahan lutut dengan baik tanpa bantuan orang lain. Begitupun pada pengujian 3 (mengubah posisi kursi). Sampel A, B, C, D dan E mampu mengubah posisi dari posisi duduk ke posisi berdiri menggunakan tuas pada bagian samping kanan kursi dan kembali ke posisi duduk dengan menekan handle yang juga terpasang pada tuas tersebut. Hasil pengujian menunjukkan bahwa KCP berfungsi dengan baik, termasuk komponen-komponen pendukung lainya seperti penahan lutut, penahan perut, dan meja.

Tabel 1. Hasil Pengujian Kursi Celebral Palsy

\begin{tabular}{|c|c|c|c|}
\hline $\begin{array}{c}\text { Jenis } \\
\text { Pengujian }\end{array}$ & $\begin{array}{l}\text { Kemampuan penguji } \\
\text { operasikan alat sendiri }\end{array}$ & Beban & $\begin{array}{l}\text { Kinerja } \\
\text { Alat }\end{array}$ \\
\hline \multirow{5}{*}{$\begin{array}{l}\text { Mengatur } \\
\text { Posisi Meja }\end{array}$} & Tidak Mampu & Sampel A & Baik \\
\hline & Tidak Mampu & Sampel B & Baik \\
\hline & Mampu & Sampel C & Baik \\
\hline & Mampu & Sampel D & Baik \\
\hline & Tidak Mampu & Sampel E & Baik \\
\hline \multirow{5}{*}{$\begin{array}{l}\text { Mengatur } \\
\text { Posisi } \\
\text { Penahan } \\
\text { Lutut }\end{array}$} & Mampu & Sampel A & Baik \\
\hline & Mampu & Sampel B & Baik \\
\hline & Mampu & Sampel C & Baik \\
\hline & Mampu & Sampel D & Baik \\
\hline & Mampu & Sampel E & Baik \\
\hline \multirow{5}{*}{$\begin{array}{c}\text { Merubah } \\
\text { posisi Kursi } \\
\text { (duduk- } \\
\text { berdiri- } \\
\text { duduk) }\end{array}$} & Mampu & Sampel A & Baik \\
\hline & Mampu & Sampel B & Baik \\
\hline & Mampu & Sampel C & Baik \\
\hline & Mampu & Sampel D & Baik \\
\hline & Mampu & Sampel E & Baik \\
\hline
\end{tabular}

KCP sebagaimana Gambar 1b (KCP 1b) memiliki dimensi dan fungsi yang berbeda dengan KCP yang dibuat oleh Wijaya [5]. KCP 1b memiliki dimensi yang lebih besar dengan fungsi untuk melatih penderita $\mathrm{CP}$ bergerak dari posisi duduk hingga berdiri, dan duduk kembali.

Bersdasarkan dengan bahan-bahan yang digunakan dalam pembuatan kursi tersebut maka harga KCP berkisar Rp 8.000.000 s.d Rp 10.000.000. Harga ini jauh lebih murah dibandingkan dengan kursi ES yang berkisar Rp 30.000.000.

\section{Kesimpulan}

Sebagaimana uraian sebelumnya, maka disimpulkan bahwa:

1. Kursi celebral palsy dapat berfungsi seperti Easy Stand.

2. Harga Kursi Celebral Palsy lebih murah dari Easy Stand

\section{Ucapan Terima Kasih}

Kegiatan penelitian ini terlaksana atas bantuan dari pimpinan Politeknik Negeri Ujung Pandang (PNUP), baik bantuan dana melalui DIPA PNUP, maupun bantuan berupa izin penggunaan segala fasilitas bengkel dan laboratorium yang ada di lingkungan PNUP. Oleh karena itu, kami tak lupa mengucapkan terima kasih yang tak terhingga.

\section{Daftar Pustaka}

[1] Kharisma, A., Indrojarwo, B.T. 2016. Desain Kursi Roda dengan Sistem Kemudi Tuas sebagai Sarana Mobilitas bagi Anak Penderita Cerebral Palsy Usia 6 hingga 10 tahun. Jurnal Sains Dan Seni, 5(2):271-275.

[2] Cahyaningtyas, A. 2016. Upaya Peningkatan Kemampuan Berpakaian Melalui Metode Drill Pada Anak Cerebral Palsy Di Sekolah Luar Biasa Daya Ananda. Skripsi. Yogyakarta : Universitas Negeri Yogyakarta.

[3] Saputra, Robby. 2012. Alat Bantu Berjalan Pasien.http://robbysaputrasiakper.blogspot.co.id/2012/04/sopalat-bantu-berjalan-pasien.html diakses 25.02.2017.

[4] Handayani, V. 2009. "Melatih Keterampilan Berpakaian Anak Keterbelakangan Mental Ringan dengan Menggunakan Teknik Total Task Presentation Chaining”. Jurnal Psikomedia, 6(2):1928.

[5] Wijaya, R.S. 2014. Alat Bantu Cerebral Palsy http://www.ubaya.ac.id/2014/content/vote/1417/MahasiswaUbaya-ciptakan-alat-bantu-cerebral-palsy.html diakses 25.02.2017. 